\title{
Multiplex Real-time Polymerase Chain Reaction Assay
}

National Cancer Institute

\section{Source}

National Cancer Institute. Multiplex Real-time Polymerase Chain Reaction Assay. NCI

Thesaurus. Code C158250.

An assay technique that utilizes the polymerase chain reaction (PCR) method to amplify multiple DNA sequences in a single cycle, with the accumulation of amplification product being measured as the reaction progresses. 